\title{
Wybrane leksykalne sposoby wyrażania wartości w pismach uczniów szkół średnich
}

Analiza leksykalnych sposobów wyrażania wartości występujących w tekstach uczniowskich zamieszczanych w gazetach szkolnych wpisuje się w nurt badań języka młodzieżowego i uczniowskiego. Język ten bowiem zgodnie z zamierzeniami zawartymi w dokumencie prawnym MEN, czyli Podstawie programowej kształcenia ogólnego dla liceów ogólnokształcacych, liceów profilowanych i techników $w^{1}$, ma być nie tylko narzędziem pozwalającym kształcić różnorodne umiejętności językowe, sam bowiem stanowi podmiot działań dydaktycznych, również w sferze komunikowania wartości². Taki zapis, znajdujący się w akcie prawnym MEN, jest efektem zapoczątkowanej w latach dziewięćdziesiątych ubiegłego stulecia mody na tzw. kształcenie ku wartościom, określane często jako edukacja aksjologiczna.

Pomimo tak wyraźnych wskazań zawartych w dokumentach oświatowych zauważyć można, że w edukacji szkolnej zaniedbuje się sferę kształcenia językowego, której celem jest wyrabianie świadomości istniejących językowych środków aksjologicznych, a także praktyki ich wykorzystywania. W wielu podręcznikach brak jakichkolwiek materiałów pokazujących język jako narzędzie pozwalające wartościować otaczający ucznia świat. Pierwsze próby widoczne są m.in. w podręczniku Haliny i Tadeusza Zgółków ${ }^{3}$, w którym mimo dość

${ }^{1}$ Podstawa programowa z komentarzami, t. 2: Język polski w szkole podstawowej, gimnazjum i liceum, s. 43-49, http://www.reformaprogramowa.men.gov.pl/images/Podstawa_programowa/men_2.pdf.

${ }^{2}$ Perspektywę aksjologiczną widać m.in. w punktach 1-6 w akapicie trzecim. Natomiast w Podstawie programowej dotyczącej nauczania języka polskiego w zakresie podstawowym sfera języka i wartości występuje m.in. w punkcie 5 Zadań szkoły, a patrząc na Treści nauczania - wskazać tu można m.in. punkty 3 oraz 4.

${ }^{3}$ H., T. Zgółkowie, Mówię, więc jestem, Kraków 2002. 
dobrze przedstawionego problemu wartościowania w języku, zagadnienie to traktowane jest jako nadprogramowe, określono je bowiem tak, jak zagadnienia dla profilu rozszerzonego. Oznacza to zatem, że w wielu klasach o profilu podstawowym czy niehumanistycznym nauczyciel pominie zawarte $\mathrm{w}$ tym rozdziale wiadomości.

W sytuacji takiej niezgodności pomiędzy zakładanymi celami dydaktycznymi i praktyką szkolną, uzasadnione stało się sprawdzenie tego, jak wygląda świadomość aksjologiczna uczniów szkół ponadgimnazjalnych. W niniejszym artykule omówiona zostanie tylko sfera leksykalna jako system najmocniej związany z waloryzacją aksjologiczną. Wybór tego podsystemu tłumaczyć można również tym, że leksyka pozwala przedstawić językowy obraz świata zawarty w tekstach uczniowskich ${ }^{4}$.

Do analizy wybrałam pisma szkolne, gdyż stanowią one zbiór autentycznych tekstów uczniowskich pisanych do konkretnego adresata - młodzieży szkolnej. Ma to bezpośredni wpływ na sposób pisania i dobór środków językowych. Mam jednak pełną świadomość, że wnioski wypływające z przeprowadzonych badań należy traktować z pewną rezerwą, ponieważ nie są to teksty prezentujące standardowe, przeciętne uczniowskie wypowiedzi pisane. Pismo bowiem tworzone jest przez grupę uczniów, najczęściej z zacięciem dziennikarskim, dla których pisanie tekstu nie stanowi problemu. Są to często uczniowie dobrzy lub bardzo dobrzy, niemający problemów z nauką przedmiotów humanistycznych. Trzeba zwrócić również uwagę na to, że pismo tworzone jest w specyficznym środowisku, jakim jest szkoła, a zatem teksty przygotowywane przez uczniów z pewnością nie zawsze wolne są od nauczycielskiej cenzury czy ograniczeń spowodowanych istnieniem obszaru tabu (o szkole, dyrekcji czy nauczycielach nie można mówić źle).

Do analizy wybrałam 117 pism uczniów szkół ponadgimnazjalnych, z każdego z nich do ekscerpcji materiału wykorzystałam co najmniej trzy numery z lat 2000-2004. Wybór tej grupy wiekowej spowodowany był tym, że młodzież ta jest w okresie, który charakteryzuje się zdobywaniem coraz większej świadomości, kształtowaniem się tożsamości młodego człowieka. Jest to zatem czas, w którym nierzadkie są oceny otaczającej rzeczywistości ${ }^{5}$.

${ }^{4}$ J. Bartmiński, Miejsce wartości w językowym obrazie świata, w: Język w kręgu wartości, red. J. Bartmiński, Lublin 2003, s. 64.

${ }^{5}$ Miałam możliwość porównania pism ponadgimnazjalnych z gimnazjalnymi, a także z pismami uczniów szkół podstawowych, w których widoczna była „cenzura” nauczycielska, teksty sprawiały często wrażenie sztucznych, przesiąkniętych ocenami nauczycieli. $Z$ doświadczenia zdobytego na praktykach w szkole, a także z rozmów z nauczycielami - redaktorami gazetek uczniowskich wiem, że we wcześniejszych etapach nauczyciel jest nie tylko osobą koordynującą prace dziennikarskie, ale często też swoistym dyktatorem narzucającym tematy artykułów i sposób ich przedstawienia. 
Omawiając leksykę wartościująca, a także opisując świat wartości występujący w pismach uczniowskich, opieram się na hierarchii aksjologicznej zaproponowanej przez Jadwigę Puzyninę. W książce Język wartości ${ }^{6}$ badaczka przedstawia siedmiostopniowy układ wartości stanowiący rozwinięcie propozycji Maxa Schelera ${ }^{7}$ Zaczynając od najniżej umieszczonych klas wartości, J. Puzynina wyróżnia następujące: wartości hedonistyczne, dla których centrum znaczeniowym jest szczęście własne - nieszczęście, nieco wyżej znajdują się wartości witalne (życie własne, zdrowie - śmierć, choroba), następnie obyczajowe (zgodność z obyczajem - niezgodność z obyczajem), moralne (dobro bliźniego - krzywda bliźniego), estetyczne (piękno - brzydota ${ }^{8}$ ), poznawcze ( prawda - niewiedza, bład). Na szczycie umieszczone są wartości transcendentne (dobro transcendentne - zło transcendentne). Wśród wartości transcendentnych wyróżnić można dwie podgrupy - sacrum - wartość transcendentną o charakterze uniwersalnym i sanctum - wartość najwyższą odnosząca się tylko do Boga'.

Przechodząc do omawiania leksykalnych środków aksjologicznych, warto zwrócić uwagę na swoistą klasyfikację sposobów wartościowania podaną przez J. Puzyninę:

Środki wyrażania wartościowań dzieli się przede wszystkim na systemowe, skonwencjonalizowane oraz tekstowe, fakultatywne, zależne od kontekstu. Z tym podziałem krzyżuje się podział tych środków na parajęzykowe (gesty, intonacja, symbolika dźwiękowa i graficzna) oraz językowe: fleksyjne, składniowe, słowotwórcze (te należą do środków systemowych), leksykalne (systemowe bądź tekstowe), wreszcie oparte na frazeologizmach i tropach skonwencjonalizowanych, a także na tropach i figurach tekstowych, charakterystycznych zwłaszcza dla języka o funkcji poetyckiej ${ }^{10}$.

Jak wynika z przytoczonych słów, leksyka jest środkiem wartościującym, który niejako przełamuje zarysowany przez badaczkę podział na wartości systemowe i kontekstowe ${ }^{11}$. W niniejszym artykule za leksykalne środki wyra-

${ }^{6}$ J. Puzynina, Język wartości, Warszawa 1992, s. 39-43.

7 Typologia zawarta w książce J. Puzyniny, Język wartości, s. 33-34.

${ }^{8}$ Rozpatrywane jednak w perspektywie nieegoistycznej.

${ }^{9}$ B. Chrząstowska, S. Wysłouch, Poetyka stosowana, Warszawa 2000, wyd. 3 zmien., s. $72-74$

${ }^{10}$ J. Puzynina, op.cit., s. 111.

${ }^{11}$ W innym artykule J. Puzynina wyraźnie podkreśla, że „stopień skonwencjonalizowania elementów wartościujących rozkłada się na skali od pełnej konwencjonalizacji, poprzez konwencjonalizację właściwą różnym grupom użytkowników danego języka czy też różnym gatunkom tekstów, aż po skonwencjonalizowanie w obrębie czyjegoś idiolektu" (J. Puzynina, Wokót języka wartości, w: Język w kręgu wartości, red. J. Bartmiński, Lublin 2003, s. 30). 
żania ocen aksjologicznych uznaję również frazeologizmy postrzegane jako jednostki leksykalne o znaczeniu globalnym. Ukazując leksykalne środki wartościowania, postaram się ukazać podział na środki systemowe i kontekstowe, a także wskazać przykłady swoistego „pogranicza”, w których trudno jednoznacznie stwierdzić, jaki sposób wartościowania ukazują.

\section{Wartościowanie systemowe}

Leksyka jako przykład wartościowania systemowego w tekstach uczniowskich dzieli się wyraźnie na dwie podgrupy ukazujące różnorodne sposoby wyrażania ocen aksjologicznych. Pierwszą, niezbyt liczną grupę tworzą leksemy prymarnie wartościujące (których znaczenie sprowadza się właśnie do przekazywania informacji wartościującej). Wymienić tu można leksemy: dobry, zhy, pozytywny, negatywny, ujemny, dodatni, zło, dobro itp.

W drugiej, dużo obszerniejszej grupie występują leksemy sekundarnie wartościujące (zwane też leksemami opisowo-wartościującymi), których cechą charakterystyczną jest występowanie nie tylko semu wartościującego, ale też semu opisowego. Wśród tych „słów barwiących aksjologicznie świat” ${ }^{12}$ znaleźć można leksemy należące do różnych kategorii gramatycznych m.in. rzeczowniki: morderstwo, kłamstwo, miłość, wstręt, szczęście, zawiść, zemsta, kłopot, grzesznik, a także bardzo rozbudowaną grupę przymiotników i imiesłowów, jak: ładny, ludzki, przygnębiający, szczęśliwy, grzeszny, budujacy, ciekawy, modny, wymarzony, zadowolony, życzliwy, upragniony, myślacy, oraz przysłówki: ładnie, nieprzyjemnie, spoko, super, po chamsku, cool, a także nieco rzadsze czasowniki: wyładnieć, poszerzać (horyzonty), rozwijać (umiejętności), zabić, szanować, bać się, leczyć, pomagać.

Omawiając leksykalne środki wartościowania charakterystyczne dla systemu językowego, należy również zwrócić uwagę na frazeologizmy. Ich znaczenie wartościujące jest niejednokrotnie bardzo czytelne. Frazeologizm jako jednostka leksykalna wskazuje na daną wartość w sposób podobny do leksemu prezentowanego przez jeden wyraz. I tak wśród nacechowanych aksjologicznie frazeologizmów w gazetkach uczniowskich pojawiają się dobrze znane frazeologizmy, utrwalone tradycją, spośród których wymienić można chociażby: być na topie, owijać w bawetne, robić byki, stroić fochy, powiać nuda, pięta achillesowa, robić z igły widly, marzyć o niebieskich migdałach, przypaść komu do gustu, patrzeć krzywym okiem na coś/kogoś, kuć na blachę, wyjść na

${ }^{12}$ Określenie zastosowane przez T. Zgółkę w artykule: Język jako filtr aksjologiczny, w: Zagadnienia komunikacji językowej dzieci i młodzieży, red. J. Porayski-Pomsta, Warszawa 1991, s. 12. 
ludzi, coś w sobie mieć, coś przecieka komuś przez palce, być (prawdziwa) połówka pomarańczy, odzyskać nadzieję na lepsze jutro, rozminać się z rzeczywistościq itp. Ponadto wskazać można frazeologizmy charakterystyczne dla języka młodzieżowego, jak np.: obryć się na maksa, ścibolić każdy grosz, być Łosiem (ale z ciebie Łoś) itp.

Stosowanie frazeologizmów ubarwia świat językowy czasopism uczniowskich, zarazem pozwala na wskazanie określonych kręgów wartości, wśród których najczęściej pojawiają się wartości moralne, obyczajowe, a także odczuciowe (hedonistyczne). Spowodowane jest to zapewne tym, że frazeologizmy oddają zebrane przez pokolenia doświadczenia ludzkie, wśród których najważniejsze są oceny dotyczące moralności (dobra/zła), a także przyjętego i powszechnie akceptowanego obyczaju, antropocentryzmu oraz swoistego egoizmu - wyrażającego się w tworzeniu jednostek odnoszących się do wartości odczuciowych (czyli sfery cielesnej, nie duchowej).

Do grupy leksemów prymarnie wartościujących zaliczyć można też charakterystyczne dla języka młodzieżowego leksemy wielowartościowe. Jednostki te mogą się bowiem wiązać z różnymi klasami wartości. Systemowość jednej podgrupy tych leksemów polega na tym, że zawierają wpisany niejako w definicję określony znak wartości - fajny, super, cool, wporzo, spoko, $O K$. (inna pisownia: O.K., OK, ok., okey), oki, bombowo, zarabiście. Do tej grupy należą również przymiotniki dobry, zły i przysłówki dobrze, źle. Ich kontekstowy charakter widoczny jest w swoistej niepełności znaczeniowej leksemów, bowiem prócz wskazania na wartość pozytywną czy negatywną nie zawierają one semu pozwalającego związać wybraną jednostkę z określoną klasą wartości.

Wśród leksemów wielowartościowych odrębnie omówić trzeba takie jednostki leksykalne, jak: strasznie i cholernie, które wartościują pozytywnie bądź negatywnie w zależności od kontekstu, w jakim się znajdują (są zatem przykładem wartościowania tekstowego) - np.: strasznie śmieszny, strasznie glupi, strasznie dobry, cholernie ładne, cholernie ciężko. Leksemy te funkcjonują zatem jako cząstki niosace informację o zabarwieniu emocjonalnym wyrazu lub wyrazów znajdujących się w najbliższym kontekście, intensyfikując zarazem znaczenie wartości. Można powiedzieć, że są swoistymi synonimami leksemu bardzo. Zaznaczyć trzeba, że leksem cholernie rzadko występuje w gazetkach szkolnych. To ograniczenie występowania spowodowane jest zapewne tym, że opisywany leksem należy do grupy wulgaryzmów, czyli wyrazów negatywnie postrzeganych przez użytkowników języka i środowisko nauczycielskie.

Ponadto leksemy straszny i cholerny jako określenia rzeczownika wskazują w pismach uczniowskich z reguły wyłącznie wartościowanie negatywne (i ten znak wartości pozwala mówić o nich w perspektywie wartości systemo- 
wych), co widoczne jest w przykładach: cholerna buda, cholerny dzień, cholerny pech, straszny widok, straszna rudera, straszny stan itp. Wartościowanie negatywne występuje również wtedy, gdy omawiane przymiotniki odnoszą się do rzeczownika nienacechowanego emocjonalnie: cholerny dzień, cholerny kraj, straszny widok czy straszny stan.

Jako synonimiczne wobec leksemu bardzo traktować należy również przysłówki, takie jak: niezwykle, nadzwyczaj, wyjatkowo, niebywale, nieźle, niesamowicie, np. niezwykle cenny, wyjatkowo dobrze, niebywale wygladać, niesamowicie dobrze itp. Do grupy tej zaliczyć można także przymiotniki o podobnym znaczeniu - wyjatkowy, nadzwyczajny, niespotykany, niesamowity, niezły (w znaczeniu dobry bądź bardzo dobry), np.: niesamowite wrażenia, niespotykany widok, niesamowity czlowiek itp. Nieprzypadkowo jednak leksemy te omawiane są oddzielnie, gdyż częstość ich występowania (którą można by określić jako przesadną) w gazetkach szkolnych świadczy o swoistej modzie na te wyrazy czy nawet manierze językowej. Omawiane leksemy prócz znaczenia bardzo niosą dodatkową informację - określany przez nie obiekt pod jakimś względem wyróżnia się spośród innych, jest rzadki, niespotykany i cenny (dlatego najczęściej wartościowany pozytywnie).

Fabuła nowego Wolfa jest znacznie ciekawsza od jego poprzednika. Sama gra zaczyna się niezwykle interesująco. [...] Gra jest niezwykle dopracowana, próżno szukać w niej jakichś błędów technicznych czy też poważniejszych bugów. („Masz Wiadomość”, II/2002, s. 6)

W opinii uczniów nauczyciel to osobnik wyjątkowo nieciekawy i pozbawiony poczucia humoru. („LIKE”, XI/2001, s. 2)

Niektórym aerobik może kojarzyć się tylko z przyjemnością i tańcem, a tak naprawdę przychodząc tutaj można się nieźle zmęczyć. (,Wzrok Ludu”, II/2002, s. 18)

Niezły z niego jeździec. (,Wzrok Ludu”, IV/2002, s. 14)

Nieco wyczerpani, aczkolwiek niebywale zadowoleni wracamy do domu. („LIKE”, X/2001, s. 9)

Polecam kiełki roślin, ponieważ są niezwykle cennym źródłem witamin i składników mineralnych. („Teraz My...”, 36/2001, s. 6)

Aby mieć przyjemność obcowania z tym niezwykle miłym człowiekiem, należy udać się do szkolnego pedagoga, bo tam właśnie wykonuje swoje obowiązki pan Sternik. (,W-Zeta”, III/2002, s. 6) 
Człowiek ten ma niezwykły dar udzielania swych uczuć innym. [...] Właśnie taki człowiek - niezwykle sympatyczny, inteligentny i charyzmatyczny - najlepiej potrafi ukazać sedno tej muzyki. („Teraz My...”, 32/2001, s. 10)

W powyższym przykładzie oprócz przysłówka niezwykle występuje również przymiotnik niezwykły określający rzeczownik dar. Dzięki niemu pozytywnie wartościujący leksem dar zostaje jeszcze bardziej nacechowany pozytywnie - przymiotnik niezwykły sprawia, że określany przez niego rzeczownik jest uwypuklony, a denotat, na który wskazuje, wyróżniony.

Przymiotnik szczególny i przysłówek szczególnie także wprowadzają informację o swoistym stopniowaniu wartości wyrażonej leksemem określanym przez opisywany przymiotnik bądź przysłówek, jak w przykładach:

Zalecamy szczególną ostrożność. („Teraz My...”, 34/2001, s. 10)

To przedstawienie było szczególnie interesujące. („Chochlik”, V/2000, s. 16)

To było szczególnie ważne. („Czytadełko”, III/2002, s. 8)

Na wartościowanie negatywne natomiast wskazują leksemy niosące znaczenie nieokreśloności. Wśród nich znajdują się zaimki nieokreślone - jakoś, byle jak, byle gdzie, byle kto, a także wyrażenie tak sobie:

Jeśli lubisz to, co robisz, z pewnością nie będziesz tego robić byle jak. („Peryskop", II/2003, s. 15)

Gdy czujesz się byle jak, spróbuj zastosować nasze metody, by pozbyć się złego nastroju, wszechogarniającej Cię chandry. („Czarno na białym”, XI/2001, s. 9)

Znaczenie wartościujące niesie również leksem niejako niesamodzielny znaczeniowo - przyimek $d z i e ̨ k i$, zawierający wskazanie na wartościowanie pozytywne przenoszone na pozytywną waloryzację czynności bądź osoby wyrażonej leksemem tworzącym wraz z nim wyrażenie przyimkowe. Jadwiga Puzynina leksem ten zakwalifikowała do środków składniowych (scharakteryzowała go jako wskaźnik zespolenia ${ }^{13}$ ), jednak uważam, że pomimo zależności semantycznej pomiędzy leksemem dzięki a konstrukcją składniową gdyby nie..., to..., wyraz dzięki funkcjonuje w zdaniu jak przyimek, wyznacza relacje między składnikami, a nie wypowiedzeniami.

\footnotetext{
13 J. Puzynina, Język wartości, s. 116.
} 
Dzięki niej [adrenalinie - M.W.P.] znika zmęczenie, odprężasz się, a z każdym kolejnym krokiem przybywa ci energii. [...] Dzięki tańcowi przełamujesz nieśmiałość i łatwiej nawiązujesz kontakty towarzyskie. („W-Zeta”, XI/2001, s. 4)

Musimy więc polubić lekcje wychowania fizycznego, ponieważ dzięki aktywności fizycznej mamy młodszy wygląd, jesteśmy sprawniejsi i zdrowsi. („LIKE”, $\mathrm{X} / 2001$, s. 11)

W kolejnym przykładzie wartościowanie pozytywne niesione przez przyimek dzięki może pozornie wydawać się wartościowaniem sprzecznym z zawartością zdania i stereotypową oceną kontekstowo wpisaną w znaczenie leksemu ściaga. Przewartościowanie ściag spowodowane jest tu między innymi tym, że wyraz ten występuje w zależności formalnej od przyimka dzięki:

Dzięki ściagom poprawiamy nasz spryt, refleks, koncentrację, spostrzegawczość i pomysłowość. Nie można nie kochać ściąg. („LIKE”, IX/2001, s. 7)

Podobnie do leksemu dzięki funkcjonuje przyimek przez, po którym zostaje wskazany sprawca negatywnego wartościowania bądź czynność przyczyniająca się do powstania sytuacji waloryzowanej ujemnie:

To wszystko przez to zmęczenie. (,Byle do dzwonka”, VI/2001, s. 13)

Agnieszka powiedziała wtedy, że przez Ankę nie zdążyła na pociąg. (,Jedenastka”, II/2003, s. 13).

Omawiając leksykę, należy również wskazać na funkcjonowanie nazw własnych z kręgu wartości transcendentnych, które czasami występują w gazetkach szkolnych, najczęściej w artykułach dotyczących świąt Bożego Narodzenia czy Wielkanocy. Nomina propria odnoszące się do postaci świętych lub apostołów (św. Piotr, św. Łukasz, św. Faustyna itp.), a także postaci boskich (Bóg, Maryja, Jezus Chrystus, Duch Święty) oraz autorytetów kościelnych (najczęściej przywoływana jest postać Jana Pawła II), a także nazwy świąt (heortonimy) związane z rokiem liturgicznym Boże Ciało, Boże Narodzenie, Wielkanoc, Zaduszki) wprowadzają do tekstu wartości transcendentne. Sa zatem jednym ze sposobów wartościowania występującego w języku, za pomocą którego tekst artykułu zawierającego wymienione nazwy własne staje się tekstem nacechowanym aksjologicznie. Dodać należy, że wartościowanie zawarte we wskazanych nazwach własnych jest sposobem waloryzacji różniącej się nieco od wartościowania systemowego, w moim przekonaniu jednak nie jest 
również przykładem aksjologizacji czysto tekstowej/kontekstowej. Łucja M. Szewczyk wskazała:

Nazwy własne i deskrypcje jednostkowe w funkcji aksjologicznej wzbogacają leksykalne środki wartościowania w języku poetyckim [i nie tylko M.W.P.].Wartościowanie apelatiwów opiera się na nacechowaniu wartościami ich struktury semantycznej, natomiast specyficzną własnością nazw wlasnych jest ich asemantyczność. Podstawowym sposobem wartościowania za pomocą nazw są więc konotacje wartościujące [podkr. - M.W.P.] ${ }^{14}$.

Choć należy zgodzić się z autorką, że wartościowanie zawarte w nazwach własnych oparte jest na istnieniu swoistych konotacji wartościujących, to w przypadku omawianej grupy nazw dodać trzeba, że konotacje te są uwarunkowane kulturowo. W kulturze polskiej propria te wyznaczają sferę wartości najwyższych dla chrześcijanina, wpisanych niejako w znaczenie podstawowe omawianych nazw własnych, stanowią zatem sferę konotacji obligatoryjnych i powszechnych, funkcjonujących podobnie do znaczeń apelatywów (stanowiących przykład wartościowania systemowego).

\section{Wartościowanie kontekstowe}

Wartościowanie kontekstowe to drugi rodzaj wartościowania, dużo bardziej interesujący, a czasami wręcz zaskakujący dla badacza. Magdalena Danielewiczowa, pisząc o konotacji wartościującej, stwierdza:

Środki leksykalne, za pomocą których dokonuje się wartościowań można bowiem podzielić na dwie grupy. Do pierwszej z nich weszłyby wyrazy wartościujące w sposób stały ${ }^{15}$, językowy, tzn. takie, dla których ocena stanowi jedną z cech definicyjnych, jest komponentem wąsko rozumianego znaczenia [...], jak i opisowo-oceniające [...]. Drugą grupę stanowiłyby środki leksykalne wartościujące w sposób niestały, tzn. takie, do których ocena dołączana jest na zasadzie silnej kulturowej asocjacji i/lub uaktywnia się jedynie w pewnych kontekstach. Można by je nazwać oceniającymi pragmatycznie ${ }^{16}$.

${ }^{14}$ Ł.M. Szewczyk, Funkcja wartościujaca nazewnictwa literackiego, w: Onomastyka literacka, Olsztyn 1993, s. 152.

${ }^{15}$ Są to opisane już we wcześniejszej części pracy leksykalne środki systemowe wprowadzające wartościowanie.

${ }^{16}$ M. Danielewiczowa, O pojęciu konotacji wartościującej, w: Studia semantyczne, red. R. Grzegorczykowa, Z. Zaron, Warszawa 1993, s. 136. 
Tę drugą grupę środków oceniających pragmatycznie według autorki tworzą a) konotacje ogólne (wspólne dla wszystkich użytkowników), b) konotacje środowiskowe (odnoszące się do tzw. dialektów języka wartości), c) rodzinne (które powstają nie tylko w środowisku rodzinnym, ale również w grupach nieformalnych) oraz d) indywidualne (odnoszące się do przeżyć i doświadczeń danej jednostki ${ }^{17}$. Podział konotacji zaproponowany przez M. Danielewiczową dokonany był na podstawie powszechności występowania danej konotacji. $\mathrm{W}$ artykule podział ten został częściowo uwzględniony, ponieważ jednak celem pracy jest wskazanie leksykalnych sposobów wartościowania, swą uwagę skupiłam nie na typach konotacji, lecz na sposobach wykorzystania kontekstu (rozumianego nie tylko jako sąsiedztwo wyrazów, ale również jako kontekst kulturowy, jakim jest stereotyp).

\subsection{Dookreślanie znaczenia leksemu}

Najciekawszym kręgiem leksyki wartościującej są te wyrazy, których konkretna wartość pojawia się dopiero dzięki umieszczeniu w kontekście innej jednostki nacechowanej aksjologicznie lub dookreślającej rodzaj wartości. Wśród leksemów charakterystycznych dla tego typu wartościowania znajdują się przymiotniki: wart, godny/godzien, peten, godny podziwu, wart zachodu, godny naśladowania, peten energii, peten śmiechu, pełen pomystów, a także czasowniki: dodać odwagi, likwidować przemoc, wpływać negatywnie, odzyskać wolność itp. Wskazać należy, że wymienione przymiotniki najczęściej występują z leksemami nacechowanymi pozytywnie, bardzo rzadko spotkać można wskazanie na wartości negatywne - pełen kłopotów, petna zmartwień, peten nienawiści.

Czasowniki natomiast są grupą, której znaczenie aksjologiczne w wielu wypadkach odczytywać można tylko na podstawie kontekstu, bowiem poszczególne leksemy czasownikowe występują z leksemami o nacechowaniu zarówno pozytywnym, jak i negatywnym. I tak czasowniki: dodać, ujać, odejmować, mogą w kontekście rzeczownika lata wskazywać na wartość przeciwną w stosunku do częstszych zastosowań, na podstawie których można by sądzić, że czasowniki te mają na stałe przypisany znak wartości: dodać lat (-) - dodać uroku (+), ujać lat $(+)$ - ujmować urody (-). Inne przykłady to likwidować np. zmarszczki, zanieczyszczenia, zarazki. Wskazywanie przeciwnego znaku wartości pojawia się wtedy, gdy czasownik występuje z leksemami wskazującymi wartościowanie pozytywne, np. likwidować miejsca pracy.

Do grupy leksemów nienacechowanych aksjologicznie i zarazem niesamodzielnych znaczeniowo należą również zaimki. Na szczególną uwagę za-

${ }^{17}$ M. Danielewiczowa, op.cit., s. 137. 
sługuje grupa zaimków wskazujących ${ }^{18}$, które w tekście pojawiają się w bliskim kontekście z leksemem wartościującym - najczęściej rzeczownikiem lub przymiotnikiem. Wtedy też zaimek funkcjonuje jak przysłówek bardzo lub przymiotnik dobry i wzmaga wartościowanie występujące w leksemie określanym przez zaimek, co uwidaczniają przykłady:

Widoki były tak piękne, że nikt nie oparł się, by nie zrobić sobie pamiątkowej fotografii. („Chochlik”, IX/2001, s. 8)

My, uczniowie, dumni jesteśmy, iż mamy tak wspaniałych nauczycieli. („LIKE”, $\mathrm{X} / 2001$, s. 3)

Jesteśmy dumni, że szacowne grono jurorów doceniło naszą ciężą pracę i przyznało „Szkolnemu Odlotowi” tak zaszczytną nagrodę. (,Szkolny Odlot”, XI/2001, s. 2)

Przedstawienie było tak śmieszne, że rozśmieszyło do łez największego ponuraka. („Masz Wiadomość”, IV/2002, s. 2)

W powyższym przykładzie zaimek tak wartościuje pozytywnie za pomocą wypowiedzenia podrzędnego okolicznikowego stopnia, w którym wypełnienie semantyczne wskazuje na wartościowanie dodatnie. Dzięki temu zaimek przysłowny wskazujący, którego treść jest dookreślona przez zdanie podrzędne, również wskazuje na wartościowanie pozytywne.

Zaznaczyć również trzeba, że użycie zaimka wskazującego przysłownego lub przymiotnego przed odpowiednio przysłówkiem, przymiotnikiem bądź rzeczownikiem otwiera miejsce dla działań perswazyjnych czy wręcz manipulacyjnych, gdyż nieokreśloność wprowadzana przez zaimek może być odczytywana w różny sposób, najczęściej jednak narzucany odbiorcy przez piszącego. Zjawisko to można również interpretować, biorąc pod uwagę emocjonalne nacechowanie języka i wtedy takie połączenia mogą stanowić wyraz emocji piszącego, który nie potrafi swych ocen wyrazić precyzyjnie za pomocą leksemów samodzielnych znaczeniowo.

Ze względu na kontekst wartościują też zaimki nieokreślone i uogólniające, np. jakiś, każdy, wszyscy. W przypadku zaimków nieokreślonych zauważyć trzeba, że bardzo często występują one jako sposób negatywnego wartościowania osoby, np. jakieś laski - pogardliwe określenie nielubianych koleżanek, które odbijają bohaterce i autorce tekstu chłopaka. Podobnie w tekście zawierającym pytanie Jak wyglada nasza szkoła na tle innych szkót? poja-

18 Typologię zaimków przyjmuję za: Z. Klemensiewicz, Podstawowe wiadomości z gramatyki języka polskiego, Warszawa 1963. 
wia się w odpowiedzi zaimek nieokreślony jakoś („Gzowski News”, XI/2001, s. 8). Wprowadza on również wartościowanie negatywne, gdyż nieokreśloność wnoszona przez zaimek jakoś, jakiś, jakieś konotacyjnie wprowadza również waloryzację negatywną. Zastosowanie zaimka nieokreślonego może bowiem tuszować odpowiedź wyraźnie nacechowaną ujemnie - zamiast odpowiedzieć, że jest źle, piszący eufemizuje swe negatywne odczucia związane z rzeczywistym doświadczeniem i za pomocą zaimka nieokreślonego łagodzi ocenę rzeczywistości, mając świadomość tego, że niejako oszukuje tym sam siebie. Również zaimek przymiotny nieokreślony w funkcji przydawki wskazuje na negatywne konotacje w przykładach: jakieś laski, jakiś kretyn, jakaś baba. Wartościowanie negatywne częściowo wprowadzane jest tu już przez sam rzeczownik, a zaimek nieokreślony ( $\mathrm{w}$ tym przypadku można scharakteryzować go jako element niosący informację niezwiązaną z nieokreślonością) jest elementem wzmagającym waloryzację negatywną.

Nieco innym sposobem wartościowania tekstowego jest zwiększenie bądź pomniejszenie znaczenia wartościującego leksemu przez kontekst, w którym został on użyty. Zwiększenie odczucia waloryzacji negatywnej zostaje osiagnięte przez stosowanie leksemu nacechowanego negatywnie jako określenia innej jednostki leksykalnej, która również należy do wyrazów waloryzujących ujemnie, np. rzeczownik choroba określony za pomocą przymiotnika nieuleczalna pozostaje w grupie słów o wartości negatywnej, jednakże wartość, na którą wskazuje rzeczownik, zostaje w ten sposób podkreślona, stopniowana. Można powiedzieć, że ten typ waloryzacji przypomina gradację przymiotnika i przysłówka, które należą do wartościowania systemowego. Podobne przykłady to: zagorzaly przeciwnik, ślepe zauroczenie, poważne klopoty zdrowotne, niekończacy się koszmar, błąd nie do naprawienia itp.

Natomiast do elementów językowych stanowiących sposób na pomniejszanie wartościowania zaliczyć można leksemy dość i dosyć, które wraz z przymiotnikiem nacechowanym aksjologicznie zmniejszają wartość wskazywaną przez przymiotnik, np. umieszczenie przysłówka dość przed sformułowaniem dobra praca sprawia, że waloryzacja pozytywna pracy zostaje nieco pomniejszona.

Pogoda była dość dobra - pozwalała na to, aby pospacerować i trochę odpocząć od uczniów. (,LIKE”, IX/2001, s. 2)

Rozmawiało się dość miło. („Masz Wiadomość”, IV/2001, s. 14)

Zrobiliśmy wtedy dosyć dużo, choć to i tak nie było wszystko. („Echo Dwójki”, III/2003, s. 12) 
Podobną sytuację zaobserwować można w przypadku leksemów niezbyt, trochę, nieco bądź zaprzeczonego przysłówka bardzo - nie bardzo:

Według mnie próbna matura okazała się niezbyt trudna. („Chochlik”, IX/2002, s. 6)

Cóż, trochę szkoda, że współpraca ze szkołą w Kolonii jakoś nie bardzo nam wychodzi. (,Europejczyk”, 3/2001, s. 3)

Jako jeden z ważniejszych portów świata, Antwerpia jest stosownie międzynarodowa i nieco zaniedbana. (,Ekspresem do Unii”, II/2002, s. 7)

Na osobną uwagę zasługuje przymiotnik dobry i jego antonim zhy. Wartościowanie pozytywne dla dobrego i negatywne dla złego jest znaczeniem wynikającym z ich definicji. Problemem jest jednak to, że typ wartości, na którą wskazuja, nie zawsze dotyczy sfery moralnej. Dobra lub zła może być zupa (w znaczeniu smaczna lub nie), samochód (np. sprawny - zepsuty), matka (łagodna - surowa), kondycja itd. W każdym z tych przypadków dopiero rzeczownik określany przez te przymiotniki dookreśla sferę wartości, z która się one wiążą. Ich znaczenie zatem w tym aspekcie uwarunkowane jest kontekstem, np. dobry psycholog, dobra matka, zła matka, dobre uczucie, dobre lody itp.

\subsection{Zmiana znaku wartości leksemu przez kontekst}

Ciekawym zjawiskiem charakterystycznym dla języka wartości omawianych czasopism jest zmiana znaku aksjologicznego wyrazu prymarnie nacechowanego na przeciwny w związku z obecnością w bliskim sąsiedztwie leksemu o innym znaku wartości - np. leksem dom, który ma kulturowo przypisaną wartość pozytywną, gdy zostaje określony za pomocą epitetu chory, patologiczny, zwichnięty, wskazuje na wartość negatywną. Podobnie wyraz przyjaciel określany za pomocą przymiotnika fatszywy również przechodzi z klasy wartości pozytywnych do negatywnych. W tej grupie znaleźć można również sformułowania: chora miłość, toksyczny zwiazek, niewesoła przygoda, wyrodna matka itp.

Do leksemów niejako wyspecjalizowanych w zmianie znaku wartości na przeciwny należy przymiotnik watpliwy, występujący najczęściej w wyrażeniu watpliwa przyjemność. Znaczenie wyrażenia zawierającego leksem nacechowany aksjologicznie określany przez przymiotnik watpliwy bliskie jest zjawisku antonimii. Innym leksemem o podobnych właściwościach aksjologicznych jest niby, który funkcjonuje jako określenie wobec rzeczownika lub 
przymiotnika, odwołuje się do frazeologizmu na niby, a nie leksemu w funkcji porównawczej. Niby przyjaciel (w znaczeniu nieprzyjaciel), niby spokój. W wyrażeniu niby porzqdek, a jednak... da się zauważyć antonimiczną funkcję leksemu niby, połączoną z konstrukcją wypowiedzenia współrzędnego rozłącznego.

Do interesujących leksemów, wpływających na wartościowanie, a obecnych we wszystkich analizowanych pismach, należą zbyt, zbytnio, za, które sytuują się w zasadzie na pograniczu środków systemowych i kontekstowych. Ich niejednolity status spowodowany jest tym, że, z jednej strony, zawsze tworzą wraz z przysłówkiem bądź przymiotnikiem o charakterze waloryzującym wyrażenia nacechowane pejoratywnie, co uwidaczniają przykłady:

Nie zrażaj się zbyt wygórowanymi wymaganiami. (,W-Zeta”, III/2002)

Może jednak nie jest za późno? („LIKE”, XI/2001, s. 8)

Bulimiczki uważają siebie za osoby nieatrakcyjne, bo zbyt grube. („LIKE”, $\mathrm{XI} / 2001$, s. 12)

Patrząc na obydwie tabele można zauważyć (oprócz tego, że pierwszoklasistom nie poszło za dobrze, a maturzyści napisali całkiem dobrze), że w ciagu tych czterech lat życia w naszej Szkole, z niezbyt dobrego ucznia, który zawitał do IV LO, w świat wypuszczamy całkiem mądrego, dorosłego człowieka! (,Gzowski News”, $\mathrm{XI} / 2001$, s. 8)

Belgowie spożywają [...] przeważnie frytki, ale są one według oceny Polaków za grubo krajane i za mało zarumienione. (,Ekspresem do Unii”, II/2002).

Przeciwnicy takich wycieczek z pewnością powiedza, że są one zbyt męczące. (,LIKE”, IX/2001, s. 6)

Natomiast, z drugiej strony, wskazanie na określoną klasę wartości zależne jest od przymiotnika lub przysłówka towarzyszącego omawianym leksemom (nie zawierają bowiem semu odnoszącego się do jednej określonej klasy wartości, jak np. leksem kłamstwo - wiadomo, że odnosi się do wartości moralnych, zdrowie - do witalnych, a wiedza - do poznawczych).

$\mathrm{W}$ wypowiedzeniu z zaprzeczeniem zbyt niesie jednak inne znaczenie, zbliżone do przysłówka bardzo:

Budynek Muzeum nie byl zbyt atrakcyjny, ale wnętrze rekompensowało wygląd zewnętrzny. (,LIKE”, XI/2001, s. 4) 
Wystawa nie byla zbyt interesująca. („Łoś”, II/2001, s. 8)

Podobnie do leksemów zbyt, zbytnio, nazbyt funkcjonuje przysłówek przesadnie, który także wskazuje na wartościowanie negatywne, spowodowane przesyceniem występowania danej wartości pozytywnej bądź negatywnej. Pojawia się on jednak dużo rzadziej, można nawet powiedzieć - sporadycznie:

Wcale nie jest prawdą, że przesadnie szczupła jest szczęśliwą (sic!). („LIKE”, $\mathrm{XI} / 2001$, s. 12)

Nie możesz przesadnie narzekać na swoją sytuację. („Kant(y)”, III/2001, s. 5)

Leksem brak, podobnie jak zbyt, zbytnio, za, łączy się najczęściej z wyrazami o nacechowaniu pozytywnym i w większości wypadków niesie waloryzację negatywną: brak dopracowania szczegótów („Łoś”, XI/2001), brak wolnego czasu („Gzowski News”, III/2002), brak miłości, brak pracy, brak perspektyw itp. Jednakże zdarza się zastosowanie leksemu brak z rzeczownikiem o nacechowaniu negatywnym i wtedy całe wyrażenie zmienia znak wartości na dodatni. Spowodowane jest to tym, że leksem brak wskazuje na nieistnienie określonej wartości nazywanej przez rzeczownik pozostający z nim w związku rządu, np. brak zmartwień, brak wirusa itp.

\subsection{Stereotyp}

Swoistym kontekstem może być również znaczenie utrwalone w kulturze wraz z przypisanym mu na stałe znakiem wartości - czyli stereotyp ${ }^{19}$, ważny w takich leksemach, jak: matka, dom, rodzina, ciepło, chłód itp. Najczęstszy sposób wartościowania w tej grupie to wykorzystanie par antonimicznych, w których rozkład wartości jest powszechnie znany, uwarunkowany kulturowo. W badanym materiale podstawowymi opozycjami wartościującymi ze względu na stereotypowe konotacje są między innymi pary:

a) jasność - ciemność (światlejszy człowiek, dodać blasku, rozjaśniać, rozświetlona/świetlista twarz/cera - szary świat, ponure myśli, mroczny nastrój),

19 Por. też: Stereotyp jako przedmiot lingwistyki: teoria, metodologia, analizy empiryczne, red. J. Anusiewicz, J. Bartmiński, Wrocław 1998, Język a Kultura, t. 12; J. Bartmiński, J. Panasiuk, Stereotypy językowe, w: Współczesny język polski. Encyklopedia kultury polskiej XX wieku, red. J. Bartmiński, Lublin 2001, s. 371-395; J. Bartmiński, Stereotyp jako przedmiot lingwistyki, w: Z problemów frazeologii polskiej i słowiańskiej, t. 3, red. M. Basaj, D. Rytel, Wrocław 1985, s. 25-53; Stereotypy i uprzedzenia, red. I. Kurcz, Z. Chlewiński, Warszawa 1992. 
b) góra - dót (szczyt szczęścia, w szczytowej formie $e^{20}-$ dno, dołek psychiczny, zdołowany),

c) swój - obcy (bliska postać, my, nasz, wy - oni, on),

d) święty (boski) - diabelski ${ }^{21}$ (czuć się anielsko, bosko - grzeszny człowiek, szatański pomyst).

W pismach uczniowskich zauważyć można, że ostatnia para święty - diabelski, wprowadzająca sferę wartości transcendentnych, nie odnosi się zazwyczaj do wartości transcendentnych, ale odczuciowych, hedonistycznych, co uwidacznia się w przykładach: czuć się anielsko, bosko, bosko wygladać, diabliczka, diablica, anielica (o wyglądzie i zachowaniu kobiety).

Mówiąc jednak o młodzieży szkolnej i analizując pisma uczniowskie, stwierdzić można, że do powyższych par dodać trzeba następujące:

a) postęp - zacofanie (nowy, nowinka, postępowy - stary, zacofany) ${ }^{22}$,

b) zwykty - niezwykty (zwyczajny, normalny, codzienny - nadzwyczajny, oryginalny, szczególny),

c) czynny - bierny (tętniacy życiem, żywy, aktywny - bierny, otęienie, letarg, sen zimowy, ospałość),

d) prawdziwy - nieprawdziwy/fatszywy (prawdziwy przyjaciel, autentycz$n y-$ fatszywa osoba) ${ }^{23}$,

e) szarość - kolor (szare życie, szaruga - różowe życie, życie nabrało kolorów), która występuje w korelacji z antynomia jasność - ciemność,

f) głęboko - ptytko (głęboki sens, gtębia stów, głębia myśli - ptytkie - o zachowaniu) odwołuje się ona nierzadko do antynomii góra - dót,

g) przód - tył (czołowy - zacofany) - para antonimów skorelowana semantycznie z antynomia postęp - zacofanie,

h) ciekawość - rutyna (nowość, zainteresowanie, hobby - nuda, codzienność) - w antynomii tej częściej wyzyskiwany jest człon nacechowany pozytywnie,

${ }^{20}$ Wyjątkiem mogą tu być sformułowania szczyt głupoty, a także wygórowane ceny.

${ }^{21}$ Por. A. Gajdzińska, Motywacja semantyczna polskich przymiotników, w: Wartościowanie w języku i tekście na materiale polskim i niemieckim, red. G. Falkenberg, N. Fries, J. Puzynina, Warszawa 1992, s. 158-159.

${ }^{22}$ Para antonimów młody - stary nie jest tu mocno eksponowana. Uczniowie podkreślają młodość jako symbol witalności, energii, życia, natomiast leksem stary zostaje niejako przewartościowany przez użycie pieszczotliwe nasi staruszkowie, zatraca tym samym negatywne skojarzenia. Poza tym w czasie powstawania tych tekstów pojawił się problem wprowadzenia nowej matury, a odchodzenia od starej. Dzięki tej problematyce można zaobserwować nierzadko zjawisko wręcz odwrotne - stara matura jest wartościowana pozytywnie, natomiast nowa negatywnie, co interpretować można jako nałożenie się kategorii stary - nowy na kategorię znany - nieznany (inaczej swój - obcy).

${ }^{23}$ Jest to bardzo często wykorzystywana przez uczniów opozycja, a zwłaszcza jej człon wartościowany pozytywnie - leksem prawdziwy. 
i) całośś - częśś (kompletnie, całkiem, zupetnie - częściowo, niezupetnie).

Powyższa antynomia nie jest w pełni reprezentowana w analizowanych pismach. Większą frekwencją charakteryzuje się człon wartościowany pozytywnie - całość, natomiast człon część występuje w analizowanym materiale tylko sporadycznie.

Podsumowując rozważania dotyczące leksyki wartościującej, warto również choćby zarysować świat wartości, który w omawianej leksyce jest zawarty. Odczytując językowy obraz świata wartości charakterystyczny dla analizowanych pism uczniowskich, zacząc trzeba od ukazania tematów poruszanych przez piszącą młodzież. Wśród najczęściej podejmowanych problemów znajdują się: szkoła, środowisko szkolne, w tym wątki ukazujące życie towarzyskie w szkole, nauczycieli i konflikty z nimi, dyrekcję, pracę szkoły, organizację i pracę Samorządu Uczniowskiego, a także artykuły związane z nauką, zdobywaniem ocen, sprawdzianami, kartkówkami itp. Drugim ważnym i częstym tematem jest dom, rodzina i życie rodzinne. Kolejne tematy to m.in. rozrywka i spędzanie wolnego czasu, dbanie o swoje zdrowie, dbanie o urodę, polityka i problemy dotyczące sytuacji ekonomiczno-gospodarczej Polski i innych krajów, relacje z rówieśnikami (przyjaźnie, a także miłości, kłótnie), informacje dotyczące szeroko rozumianej kultury (muzyka, film (kino), rzadziej teatr, opera czy operetka), święta i sposoby spędzania czasu świątecznego, tradycje świąteczne (tu nie tylko święta o charakterze religijnym, ale również te, które określane są jako komercyjne, zatem święta zaczerpnięte z kultury amerykańskiej, jak np.: walentynki czy halloween, a także związane z polską obyczajowością - Dzień Kobiet, Dzień Chłopaka itp.; zwraca uwagę bardzo rzadkie przypominanie/świętowanie ważnych dat związanych z rocznicami ważnych wydarzeń z historii Polski, jak: Konstytucja 3 maja, odzyskanie niepodległości itp.). Najrzadziej jednak poruszana jest problematyka związana bezpośrednio $\mathrm{z}$ wiarą $\mathrm{w}$ Boga i religia.

Przegląd tematyki poruszanej na łamach pism uczniowskich sugeruje występowanie w nich pełnej, siedmiostopniowej hierarchii wartości. Łatwo wskazać można grupy tematyczne, które łączą się z określonymi klasami wartości. I tak w sferze wartości hedonistycznych (odczuciowych) znajdują się takie zagadnienia, jak: dbanie o urodę czy rozrywka, witalnych - dbanie o zdrowie, a także czasami wygląd zewnętrzny (np. zdrowo wyglądające włosy czy cera), wartości obyczajowych - tu wszelkie święta o charakterze niereligijnym, szkoła: nauka, zdobywanie ocen, konkurencja między uczniami. Natomiast wśród wartości estetycznych znajdują się m.in. kultura i sztuka, czasami uroda ${ }^{24}$, a do wartości poznawczych uczniowie zaliczają problemy

${ }^{24}$ Dbanie o urodę czy szerzej wygląd zewnętrzny jest bardzo często działaniem nastawionym na osiagnięcie przyjemności. Zatem wartości te lokują się wtedy w grupie wartości odczuć, 
dotyczące wiedzy zdobywanej w szkole oraz informacji ze świata, ocenę człowieka z perspektywy jego wiedzy (doświadczenia). Wartości moralne dotyczą relacji z drugim człowiekiem ${ }^{25}$. Do ostatniej grupy - wartości transcendentnych, usytuowanych najwyżej na drabinie aksjologicznej - zaliczyć można przede wszystkim artykuły poruszające tematykę świąt religijnych i traktujące o czasie okołoświątecznym (np. czas rekolekcji, adwentu, Wielkiego Postu), w których zwraca się uwagę na sferę transcendentną - np. narodzenie Zbawiciela czy zmartwychwstanie Jezusa i oczyszczenie człowieka z grzechu, a także kwestię wiary w Boga i problematykę życia wiecznego.

Istotne jest, że z wypowiedzi uczniowskich wyłania się świat aksjologicznie uporządkowany, szanujący utrwalone wartości, sprzeczne z dzisiejszą modą na postmodernistyczny relatywizm kulturowy. Nawet jeśli uczniowie poruszają tematykę kultury popularnej, masowej, zwracają uwagę na jej negatywny wpływ na młodego człowieka. Nie przejmują bezkrytycznie wzorców narzucanych im przez świat współczesny. Oczywiście, nie jest tak, że nie pojawiają się artykuły pozytywnie oceniające współczesną kulturę, jednakże w większości przypadków młodzi dziennikarze posługują się stałą i, można rzec, tradycyjną hierarchią wartości, której porządek przypomina układ aksjologiczny zaproponowany przez Jadwigę Puzyninę.

Ponadto, przeglądając leksykalne sposoby wyrażania wartościowań występujące w pismach uczniowskich, zauważyć trzeba ich różnorodność i swoiste bogactwo. Wniosek taki przywołuje badania Kazimierza Ożoga, według którego jedną z cech języka młodzieżowego jest tendencja do posługiwania się kodem ograniczonym ${ }^{26}$. Jednakże mając na uwadze fakt, że teksty te są wypowiedziami uzdolnionych dziennikarsko młodych ludzi bądź osób sytuujących się powyżej przeciętnego ucznia szkoły średniej, wniosek ten należy traktować z pewną rezerwą. Zwrócić trzeba tu jednak uwagę na wrażliwość językową młodego człowieka, chęć i potrzebę wyrażania zdań na temat wydarzeń i rzeczywistości, które bacznie obserwuje. Faktem jednak jest, że leksyka jako środek wartościujący jest jednym z najłatwiejszych i najpowszechniejszych sposobów wyrażania ocen aksjologicznych, a jej tak liczne wyzyskiwanie w artykułach młodych dziennikarzy świadczy nie tyle o sprawności językowej, ile o potrzebie zróżnicowanego językowo wyrażania swego zdania na temat otaczającego świata szkolnego i pozaszkolnego.

nie piękno bowiem jest tu celem nadrzędnym, a chęć podobania się innym i sprawienia sobie przyjemności. Por. J. Puzynina, Język wartości, s. 41.

${ }_{25}$ Podkreśla to bardzo mocno Z. Zaron (Wybrane pojęcia etyczne $w$ analizie semantycznej. Kochaj bliźniego swego, Wrocław 1985).

${ }^{26} \mathrm{~K}$. Ożóg, Język wspótczesnej młodzieży - między kodem ograniczonym a kodem rozwiniętym, w: idem, Polszczyzna przełomu XX i XXI wieku. Wybrane zagadnienia, Rzeszów 2001, s. $176-195$. 


\section{Marta Wrześniewska-Pietrzak}

\section{Selected Lexical Means of Expressing Values in Secondary School Students`Compositions}

The aim of the article is to present characteristic lexical means of expressing values used in secondary school students ' compositions between the years 2000 and 2004.

The methods of evaluation discussed in the article have been divided into two groups that constitute an example of systemic evaluation (lexemes that evaluate primarily and secondarily) and context evaluation (specifying the meaning of a lexeme, changing the value of a lexeme by context, the phenomenon of evaluation through stereotypes). Moreover, the article points out the devices which can be placed between conventionalised and context means (e.g., multi-evaluating lexemes or proper names referring to the transcendental sphere). The analysis of lexical material enabled researchers to draw a number of conclusions that show a linguistic picture of the world of values present in students` compositions. This picture appears well-ordered and stable. Additionally, it includes all evaluation classes identified in the axiological typology compiled by Jadwiga Puzynina. 
